\title{
Broadening Student Perspectives On Marketing Research Ethics: Development And Applications Of A Teaching Module
}

Amy Handlin, Monmouth University, USA

\begin{abstract}
This paper describes an ethics module developed by the author to engage marketing research students during the fall semester, when they are bombarded by political polls. The module matches ethically questionable polling practices to similarly troubling practices in marketing research. The goals are to show that ethical principles are not topic-or context-bound and to broaden students' perspectives on ethics, in general.
\end{abstract}

Keywords: Ethics; Surveys; Polls; Privacy; Transparency; Deception

\section{INTRODUCTION}

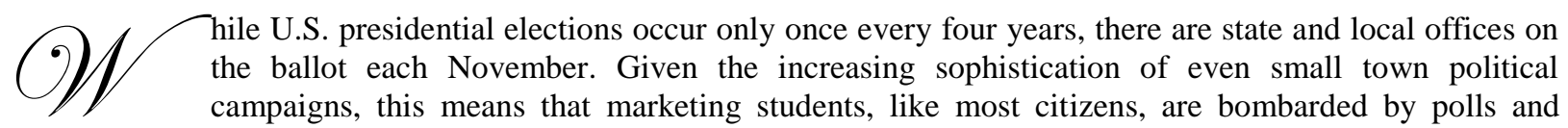
surveys about political issues virtually every fall semester.

In teaching marketing research for 15 years, the author has regularly fielded questions about how political polls relate to marketing surveys. Many of these questions are straightforward; for example, students ask about the size of national voter samples or the meaning of margins of error. Such topics fit readily into lectures and discussion about survey design and statistical issues central to marketing research.

But in the past few years, the author has noticed an increasing number of students questioning the ethics of political polls. In response, it has been helpful to designate four class sessions during October as an ethics module, during which students' observations and complaints about political polling are used as jumping-off points for broader lessons about the ethical dimensions of data gathering in marketing research and the industry's attempts to raise its collective ethical standards.

The working definition of ethics used in the module is that of Taylor (1975): "an inquiry into the nature and grounds of morality where the term morality is taken to mean moral judgments, standards and rules of conduct." The goal of expanding marketing students' horizons to help elucidate ethics dates back at least 35 years (Hawkins and Cocanougher, 1972). Importantly, the 2004 report of the AACSB (Association to Advance Collegiate Schools of Business) Ethics Education Task Force highlighted "business and society" as one of the key domains of business ethics for ongoing undergraduate and graduate management education (AACSB, 2005).

\section{CONSTRUCTION OF THE MODULE: COMPONENTS AND LEARNING GOALS}

There are three module components - two student-driven and one instructor-driven. Each has one or more specific learning goals. 


\section{Component \#1}

Students are asked to write down at least one example of questionable ethics that has occurred to them, or that they have heard/read about, relating to a political poll. They are also required to answer two questions:

- $\quad$ On what basis did you decide that this example was ethically questionable?

- What is the difference between ethics and law?

Learning Goal

The goal is to help students appreciate that what is right often transcends what is legal. Marketers are faced with many choices not addressed or imperfectly addressed in current law, especially if they do business globally.

In the first of the four dedicated class sessions, two topics are discussed. The first topic concerns behaviors that are unethical but not illegal. For example, a researcher may pressure, embarrass or even coerce individuals, like co-workers or friends, into participating in a study without breaking the law. However, it should be obvious to students that such behavior is unethical.

The second topic concerns situations where a strong law exists, but the letter of the law can be obeyed while its spirit is violated. For example, global researchers are legally obligated to comply with the European Union's 1998 Directive on Data Protection, which prohibits personal data transmission to other countries that do not meet its privacy protection standards. But U.S. researchers are not bound to provide the same degree of protection. So some domestic practitioners get around the EU Directive by collecting primary data from Europeans only while they are living or working on American soil - an approach which is technically legal, but ethically questionable.

\section{Component \#2}

The instructor sorts students' examples into categories, each designed to focus on a key principle in research ethics. To their examples of ethical issues related to political polling in each category, the instructor then matches similar examples related to marketing research. Discussion of these issues serves as the basis for two class sessions.

\section{Learning Goal}

The goal is to illustrate that proper research practices are not topic- or context-bound. More broadly, students need to understand that they have a responsibility to be vigilant - both as business persons and as citizens so as not to be taken in or lulled into complacency by shady operators.

The categories are listed below, with the basic ethics principle to which each relates. Typical student examples are matched with marketing examples.

Category \#1: $\quad$ Research practices that violate the subject's right to privacy

Key Research Ethics Principle

Researchers cannot obtain or transmit private information about a subject without his/her explicit consent.

\section{Student Examples}

- $\quad$ Telephone polls using cell phone numbers clearly obtained from lists not intended for this purpose; for instance, from unrelated membership or subscriber lists.

- $\quad$ Online polls sent to unpublished, private email addresses, or to workplace email addresses without permission or authorization. 
Instructor Examples

- In 2002, doubleclick.com became one of the first companies with the capability to capture private and sensitive information about online consumers with its embedded, undetectable "cookies." When news leaked out that doubleclick.com intended to sell advertising based on these personal profiles, an outcry from privacy advocates forced the company to withdraw its plans (Wall Street Journal, 2003). However, several years after the doubleclick.com controversy, there remains no law against gathering and/or using such information in the general consumer marketplace - and no guarantee that similar practices are not going on.

- In violation of its own privacy policy, JetBlue Airlines provided over 1.5 million customer itineraries and personal information to the data mining company, Torch Concepts. This allowed Torch to develop airline customer profiles, including social security numbers, occupations, income, number of children and other private information.

Sued by a nonprofit privacy advocacy group, JetBlue was badly embarrassed by this incident and forced to apologize to its many angry customers (Cooper and Schindler, 2006).

Category \#2: $\quad$ Research practices that deceive participants

Key Research Ethics Principle

Subjects have a right to expect honesty and transparency from research professionals.

Student Examples

- $\quad$ Telephone calls that purport to be legitimate surveys, but actually are advocacy messages couched in leading questions and attacks on an opponent.

- $\quad$ Online communications that ask for respondents' opinions but are primarily tools to identify active email addresses for campaign solicitations.

Instructor Examples

- $\quad$ The State of New York sued a company called Student Marketing Services for fraudulently gathering survey data about respondents' psychographic and demographic characteristics. The students were told the information would go to universities to help them gain admission.

In fact, the information went to direct marketers of credit cards, videos, cosmetics and other products (Wall Street Journal, 2002). The students were not informed of the actual uses of their data.

- $\quad$ The Coca-Cola Company hired a consultant to bump up redemption of coupons for its Frozen Coke drinks at participating Burger King stores. Courtesy of the consultant, people were given free Whoppers just to get coupons redeemed.

Coke stood to gain millions in Burger King advertising if the drink promotion was a success. However, neither Burger King officials nor their customers were told the reason for the giveaway (Wall Street Journal, 2003).

- In an unfortunate sign that the number of unscrupulous operators is growing, some legitimate marketers have invented an acronym to refer to the practice of deceiving participants: "sugging," for "sales under the guise of research" (Cooper and Schindler, 2006). 
Category \#3: Research practices that deceive the public

Key Research Ethics Principle

The public has a right to expect honesty and transparency from research professionals.

Student Examples

- $\quad$ "Spinning" of poll results by campaign spokesmen to make them sound more important or positive than they actually are.

- Television talk show "polls" based on self-selected samples.

Instructor Examples

- Increasingly, marketers of insurance products and investment services are targeting the senior (over 65) market. One tool used by some companies is a free lunch or dinner for prospects, followed immediately by a hard sell of the product or service. The sales pitch may be characterized as a "focus group" or an "educational seminar" (Gordon, 2007).

In some states, legislation is under consideration to rein in these deceptive practices, which rarely provide sufficient information to seniors or opportunities for them to clarify information that is typically complex and confusing.

- $\quad$ Sweepstakes fraud is on the rise, particularly in conjunction with 900 number call-in programs. The bogus solicitations often request consumers' personal information for research purposes, when in fact the only goal is to obtain this valuable data without paying for it (Holson, 2008, and Jackman, 2008).

(Note: This third example touches on both of the issues raised by students - "spinning" and unrepresentative samples.)

- A diet products company conducted research purporting to show that people who lose weight can keep it off. Based on these results, the company issued a statement, "There's good news for the 65 million Americans currently on a diet!" But it turned out that the "research" was based on 20 graduates of the company's program - all of whom endorsed the brand in television commercials (McDaniel and Gates, 2007).

Category\#4: Research practices that harm the industry (e.g. by making people angry and less willing to participate in future studies)

Key Research Ethics Principle

Research professionals have a responsibility to foster trust in the industry.

Student Examples

- $\quad$ Telephone polls that take up too much time: The caller says it will take just a few moments, then proceeds to ask 50 questions or more.

- $\quad$ Telephone polls conducted by a computer instead of a person, or by a poorly trained and/or discourteous interviewer 


\section{Instructor Examples}

- $\quad$ According to McDaniel and Gates (2007), the increasing length of telephone surveys and mall intercept interviews (commonly 30-40 minutes long) is one of the factors associated with refusal rates over $60 \%$.

- While poor training and lack of civility among interviewers has long been an issue in marketing research, the growing role of computer programs, called predictive dialers, has introduced problems of its own. More and more marketing research call centers now use these devices to dial phone numbers ahead of interviewer availability, thus reducing interviewer downtime. But respondents may be put on hold for significant periods or hung up on because no interviewer can take the call (Haynes, 2005).

- $\quad$ The U.S. "Can-Spam Act" prohibits marketers from sending messages to cell phones without permission from the consumer. Unfortunately, some companies engage in unsolicited texting anyway. Additionally, cell phone spam may be attached to ringtones, games or other downloads.

\section{Component \#3}

In the final class session, students are required to compose a letter or email of complaint to the candidate, political party or interest group whose polling practices they chose as an example in Component \#1. They must identify themselves as students of marketing research and explain their concerns based on what they have learned. If they are unable to identify a sponsor of the research, they are directed to write a letter to the editor of a local newspaper or a post on a political blog. (Students are not required to actually transmit the messages if it makes them feel uncomfortable, but all messages are graded as a class assignment.)

Learning Goal: to connect class discussions with the real world and encourage students to engage in an ethical debate with societal consequences

\section{ASSESSMENT}

To gauge the impact of this ethics module, the author administered a brief questionnaire (Table 1) to all members of the subject marketing research class and to an equal number of students in another marketing elective at a similar level (sophomores and juniors). The items were adapted from Gaedeke and Kelley's study of business students' perceptions of ethics (1992). A 5-point Likert scale ranged from 1=strongly agree to 5=strongly disagree. The t-test was used to compare means between the two groups.

Table 1: Assessment of Ethics Module

\begin{tabular}{|c|c|c|c|c|c|}
\hline \multirow[t]{2}{*}{ Item } & \multicolumn{2}{|c|}{ Mean } & \multicolumn{2}{|c|}{ SD } & \multirow[t]{2}{*}{ t-test Value } \\
\hline & MR[a] & ME[b] & MR & ME & \\
\hline $\begin{array}{l}\text { 1. Most marketing research decisions involve a } \\
\text { significant degree of ethical judgment. }\end{array}$ & 4.1 & 3.5 & 0.81 & 0.84 & $2.14 *$ \\
\hline $\begin{array}{l}\text { 2. It takes effort for marketing researchers to behave } \\
\text { ethically in a competitive world }\end{array}$ & 4.0 & 3.7 & 0.84 & 0.79 & 1.98 \\
\hline $\begin{array}{l}\text { 3. The ethical dilemmas faced by marketing researchers } \\
\text { are similar to those faced by political pollsters. }\end{array}$ & 4.6 & 3.4 & 0.80 & 0.83 & $2.18 *$ \\
\hline $\begin{array}{l}\text { 4. The ethical decisions of marketing researchers have } \\
\text { as much impact on ordinary people as the ethical } \\
\text { decisions of political pollsters. }\end{array}$ & 3.8 & 2.9 & 0.83 & 0.79 & $3.20 *$ \\
\hline $\begin{array}{l}\text { 5. The ethical decisions of marketing researchers affect } \\
\text { the bottom line. }\end{array}$ & 4.4 & 3.5 & 0.78 & 0.78 & $3.19 *$ \\
\hline
\end{tabular}

$* \operatorname{sign}=\mathrm{p}<0.05$

[a] $\mathrm{MR}=$ marketing research class

[b] $\mathrm{ME}=$ marketing elective class 
The respondent pools $(n=15)$ were far too small to yield generalizable findings. Directionally, however, the results were encouraging. Students who were exposed to the module in the marketing research class were significantly more aware of four of the five ethics dimensions addressed in the questionnaire.

To supplement the quantitative assessment, the instructor also offered an opportunity to each student to provide open-ended, anonymous feedback. All comments received were positive. A sampling included:

- $\quad$ I never realized that people get shafted by marketing researchers as much as by political pollsters.

- $\quad$ Thanks for teaching me how to fight back.

- $\quad$ Now I want to learn more about laws that restrict unethical market research practices.

- $\quad$ Marketing researchers and pollsters should talk to each other. By collaborating, I believe they could raise the ethics standards in both professions.

\section{CONCLUSIONS}

Anyone who teaches introductory marketing research, especially in a one-semester format, will agree that it is challenging just to cover the fundamentals of the discipline - research design, sampling, data analysis, etc.. So why devote precious class time to the issues outlined here?

An eloquent rationale comes from the work of Drumwright and Murphy (2004). In extensive interviews with advertising professionals in 29 agencies, they found an alarming state of "moral myopia" - a failure to focus on ethical issues and a willingness to justify ethically questionable practices simply because the practices are longstanding or widespread. Today's students represent the best hope for transforming moral myopia into moral vision and responsibility, as well as for raising ethical standards in the future. To the extent this module helps to engage students by connecting marketing to politics and current events, it is at least a step in the right direction.

Additionally, the rapid dissemination of primary data collected by government agencies, nonprofit advocacy groups and cultural institutions has created a generation of students highly attuned to the impact of marketing research practices on other sectors. This is a significant and promising change in outlook from that of students a decade ago who demonstrated in at least one study that they had little understanding and/or appreciation of this interconnectedness. As the author of that paper observed:

Marketing courses obviously cannot and should not teach civics or political science. However, the current realities of doing business demand some attention to basic structural and ethical issues, if only to fill in the most obvious gaps (Handlin, 1995).

\section{SUGGESTED RESOURCES}

While this module was offered only to undergraduates, it readily adaptable to marketing courses on the graduate level. To develop their own matched examples, instructors may access university-based ethics research centers and/or professional associations of research practitioners with their own codes of ethics. Samples of both types of resources are provided below:

\footnotetext{
- University-Affiliated Centers:

- $\quad$ Center for Business Ethics at Bentley College, www.bentley.edu

- $\quad$ E-Business Ethics Center at Colorado State University, www.ebusinessethics.com

- $\quad$ Emerson Ethics Center at St. Louis University, www.slu.edu

- $\quad$ Olsson Center for Applied Ethics at University of Virginia, www.darden.virginia.edu

- $\quad$ Association to Advance Collegiate Schools of Business, www.aacsb.edu

- $\quad$ Professional Associations:

- $\quad$ Council for American Survey Research Organizations, www.casro.org

- $\quad$ Marketing Research Association, www.mra-net.org

- $\quad$ American Marketing Association, www.marketingpower.com
} 


\section{AUTHOR INFORMATION}

Amy Handlin is an Associate Professor of Marketing in Monmouth University's Hess School of Business. She also served for six years as a member of New Jersey's Commission on Higher Education. Her current research focuses on the connections between business and government, especially on the state and local levels. E-mail: ahandlin@monmouth.edu

\section{REFERENCES}

1. $\quad$ AACSB International Ethics Education Task Force (2005), "Ethics Education in Business Schools," www.aacsb.edu.

2. $\quad$ Cooper, Donna and Pamela Schindler (2006), Marketing Research, McGraw Hill: New York, NY.

3. Drumwright, Minette and Patrick Murphy (2004), "How Advertising Practitioners View Ethics: Moral Muteness, Moral Myopia and Moral Imagination," Journal of Advertising 33(2), 7-24.

4. Gaedeke, R. M. and C.A. Kelley (1992), "Business Students' Perceptions of Ethics in Marketing," Journal of Education for Business 67(5), 294-307.

5. Gordon, M. (2007), "Firms Faulted Over Misleading Seniors at Investing Events," The Washington Post, Sept. 10, www.washingtonpost.com.

6. Handlin, Amy (1995), "Students' Understanding of U.S. Government-Business Relationships: An Analysis and Suggested Teaching Approach," Proceedings of the 1995 Annual Meeting of the Association of Marketing Theory and Practice, 339-342.

7. Hawkins, D. and A. Cocanougher (1972), "Student Evaluations of the Ethics of Marketing Practices: The Role of Marketing Education," Journal of Marketing 36(April), 61-64.

8. Haynes, David (2005), "Respondent Goodwill Is a Cooperative Activity," Quirk's Marketing Research Review (Feb.), 30-32.

9. Holson, L. (2008), "Spam Moves to Cell Phones and Gets More Invasive," New York Times, May 10, www.nytimes.com.

10. Jackman, T. (2008), "Families Urged to Fight Elder Mail Fraud," Chicago Tribune, August 17, 6.

11. McDaniel, Carl and Roger Gates (2007), Marketing Research, John Wiley and Sons: Hoboken, NJ.

12. "Professional Researcher Certification," www.mra-net.org.

13. Smith, Alan (2002), "Email Workplace Privacy: Critical Issues in an E-Commerce Environment," Proceedings of the Atlantic Marketing Association, 117-122.

14. Taylor, Paul (1975), Principles of Ethics: An Introduction, Dickenson Publishing Co.: Encino, CA.

15. Ferrell, O.C. and Linda Ferrell (2005), "What Your Mother Never Taught You: How to Teach Business Ethics," adapted from Fulfilling Our Obligations: Perspectives on Teaching Business Ethics, Kennesaw State University Press, 3.

16. Wall Street Journal (2002), "New York State Sues Survey Firm for Allegedly Tricking Students,” August 30, B4.

17. Wall Street Journal (2003), “How Coke Officials Beefed Up Results of Marketing Test," August 20, A1, A6. 
NOTES 